ISSN No: 2582-0559

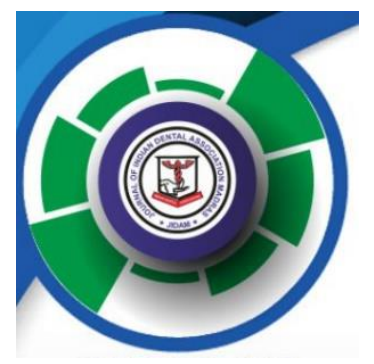

OBSERVATIONAL RESEARCH ARTICLE

\title{
TOBACCO RELATED CANCER INCIDENCE - A TIME TRAVEL COMPARATIVE ANALYSIS BEFORE AND AFTER IMPLEMENTATION OF NATIONAL TOBACCO CONTROL PROGRAMME IN INDIA
}

\author{
Dr. N. Divya Lalitha*, Dr. Prabu.D, Dr. Rajmohan, Dr. Sunayana Manipal, Dr. Bharathwaj.V.V \\ * National Oral Health Programme, Centre for Dental Education and Research, All India Institute of Medical Sciences, India \\ Department of Public Health Dentistry, SRM Dental College,Ramapuram, Chennai, Tamilnadu, India
}

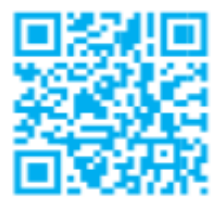

DOI: 10.37841/jidam_2021_V8_I4_02

Address for Correspondence:

Dr. N. Divya Lalitha, Research Officer,

National Oral Health Programme,

Centre for Dental Education and Research,

All India Institute of Medical Sciences, Ansari Nagar,

New Delhi -110029, India

Email id: diyan2409@gmail.com

Received: 20.02.2021

First Published: 19.03.2021

Accepted: 16.03.2021

Published: 27.12.2021

\section{ABSTRACT}

India's responsibility towards the arrangement, and progressively successful reduction in the usage of tobacco under "Cigarette and Other Tobacco Products Act" (COTPA) and "Framework Convention for Tobacco Control" (FCTC) prompted the introduction of the National Tobacco Control Program (NTCP) in 2007-2008. This study aimed to compare the incidence of tobacco related cancers before and after implementation of NTCP in India. All the sources which have the statistics on cancer incidence in India were identified and the data was extracted to compare the cancer incidences. Secondary data from the sources such as National Cancer Control Registry, Global adult tobacco survey report etc. were collected and tabulated. The results showed that the usage of smokeless tobacco has decreased to $17.6 \%$ in 2015 after the implementation of NTCP from $23.4 \%$ in 2005 . Same way the prevalence in the usage of smoked tobacco has reduced considerably from $18.3 \%$ in 2005 to $11.9 \%$ in 2009 after the implementation of NTCP. In Mumbai, the number of cancer patients due to tobacco usage has decreased from 7642 to 3625 . But in Chennai, the total number have increased from 20002014. By the analysis of incidence of tobacco related cancers and tobacco consumption in India, it is evident that the usage of tobacco products both smoke and smokeless tobacco consumption have decreased after the implementation of NTCP.

KEYWORDS: National Tobacco Control Program, tobacco related cancers, Comparison, Tobacco, India 


\section{INTRODUCTION}

Oral Cancer is one among the significant issues in the India and it takes a position in the first three kinds of cancers in the nation ${ }^{1}$. It has a significant importance in terms of public health in India.

Age-balanced rates of oral malignant growth is high in India, for instance, 20 for each 100,000 people and records for about $30 \%$ of the tumours in the nation ${ }^{2}$. The variety in incidences and prevalence of the infections can be credited to the ageing of the people, just as territorial variations in the common disease specific high risk factors ${ }^{3}$.

Basically, oral cancer is analysed at later stages which bring about low treatment results and extensive expenses to the patients who regularly can't afford this sort of treatments ${ }^{4}$. Prior discovery of oral malignant growth offers the most obvious opportunity for better prognosis and can possibly improve treatment results and make medicinal services affordable ${ }^{5}$. Oral diseases affects mainly those from lower financial status, that is, individuals from the lower financial strata of society because of a higher presentation to hazard factors, for example, usage of tobacco ${ }^{6}$. Furthermore, rural areas and low-income nations additionally have lacking access to skilled health care providers. Therefore, delay has additionally been to a great extent connected with end stages of oral cancers ${ }^{7}$.

In 2003, India ordered the "Cigarette and Other Tobacco Products Act," known as COTPA, yet the greater part of its arrangements came in 2004. In 2004, India turned into a signatory to the Framework Convention for Tobacco Control (FCTC), drove by the World Health Organization. From 2007 to 2008 ahead, the usage of all tobacco control laws is under the National Tobacco Control Cell under the National Tobacco Control Program ${ }^{8}$.

India's responsibility towards the arrangement, and progressively successful reduction in the usage of tobacco under FCTC and COTPA prompted the instigation of the National Tobacco Control Program (NTCP) in 2007-20089 . Initially created as a pilot venture in two areas in every one of nine Indian states ${ }^{10}$, the NTCP was extended in 2008 2009 to cover an aggregate of 42 districts and 21 states and has been extended to 400 regions across India ${ }^{11}$.

The key objectives of NTCP are improving the awareness about existing tobacco control laws and the destructive impacts of tobacco usage; and encourage powerful usage of tobacco control laws and strategies ${ }^{9-10}$.
There is an improved awareness about tobacco products, and reduction in the usage of tobacco products post NTCP in India. This study aimed to compare the incidence of oral cancer before and after implementation of NTCP in India.

\section{MATERIALS AND METHODS:}

This study was conducted to compare the incidence of oral cancer before and after implementation of "National Tobacco Control Program" in India. Secondary data regarding the incidence of oral cancer from 2004-2019 was collected and analysed.

The study population included patients who registered themselves having cancer according to National Cancer Control Registry. All men and women having cancer were included to compare the incidence of cancer during the year 2004-2019, i.e. before and after the implementation of National Tobacco Control Program.

The inclusion criteria included all the patients who registered themselves in the cancer control registry during the period of 2004- 2019.

Secondary data regarding the incidence of cancer in men and women were collected and compared to see the effectiveness of National Tobacco Control Program. The incidence of cancer before and after 2007 i.e. after the implementation of National Tobacco Control Program was collected from different sources to do year wise comparison. Articles from different databases such as Pub Med, Medline, Scopus etc. using the keywords tobacco related cancers and National Tobacco Control Program were collected and included in the study.

All the sources which have the statistics on cancer incidence in India were identified and the data was extracted to compare the incidences. Secondary data from the sources were collected and tabulated.

\section{RESULTS:}

\section{TABLE 1: INCIDENCE OF CANCER IN INDIA BEFORE AND AFTER NATIONAL TOBACCO CONTROL PROGRAM AMONG MALES AND FEMALES}

\begin{tabular}{|l|l|l|l|}
\hline Year & $\begin{array}{l}\text { Incidences of } \\
\text { cancer in Male }\end{array}$ & $\begin{array}{l}\text { Incidences of } \\
\text { cancer in Female }\end{array}$ & $\begin{array}{l}\text { Total No. of } \\
\text { Patients }\end{array}$ \\
\hline \multicolumn{3}{|l|}{ BEFORE National Tobacco Control Program } \\
\hline 2005 & 40000 & 43000 & 83000 \\
\hline 2006 & 40000 & 45000 & 85000 \\
\hline 2007 & 42000 & 47000 & 89000 \\
\hline AFTER National Tobacco Control Program \\
\hline 2008 & 44000 & 49000 & 93000 \\
\hline 2009 & 454842 & 507990 & 962832 \\
\hline
\end{tabular}


Divya et al: Tobacco Related Cancer before and after implementation of National Tobacco Control Program

\begin{tabular}{|l|l|l|l|}
\hline 2010 & 462408 & 517378 & 979786 \\
\hline 2015 & 55000 & 60000 & 110000 \\
\hline $\mathbf{2 0 1 9}$ & 58000 & 65000 & 123000 \\
\hline
\end{tabular}

Source: Cancer India growth statistics ${ }^{12}$

Table 1 shows the Year wise Incidence of Cancer before and after NTCP in Males and Females. It shows that there is an increase in terms of cancer patients after 2008 that is after the implementation of NTCP.

\section{TABLE 2: DISTRIBUTION OF TOBACCO RELATED CANCERS IN INDIA ACCORDING TO STATES}

\begin{tabular}{|c|c|c|c|}
\hline $\begin{array}{l}\text { CANCER } \\
\text { TYPE }\end{array}$ & $\begin{array}{c}\text { HIGHLY } \\
\text { AFFECTED STATE }\end{array}$ & $\begin{array}{l}\text { MODERATELY } \\
\text { AFFECTED } \\
\text { STATE }\end{array}$ & $\begin{array}{c}\text { LEAST } \\
\text { AFFECTED } \\
\text { STATE }\end{array}$ \\
\hline Lung & $\begin{array}{l}\text { Jammu and Kashmir, } \\
\text { Delhi, Himachal } \\
\text { Pradesh, } \\
\text { Maharashtra, } \\
\text { Rajasthan, Andhra } \\
\text { Pradesh. W. Bengal }\end{array}$ & $\begin{array}{l}\text { Manipur, } \\
\text { Uttarakhand, } \\
\text { Tripura, } \\
\text { Jharkhand, } \\
\text { Kerala }\end{array}$ & Nil \\
\hline Cervix & $\begin{array}{l}\text { Himachal Pradesh, } \\
\text { Tamil Nadu, } \\
\text { Haryana }\end{array}$ & $\begin{array}{l}\text { Goa, West } \\
\text { Bengal, } \\
\text { Rajasthan }\end{array}$ & $\begin{array}{l}\text { Punjab, } \\
\text { Andhra } \\
\text { Pradesh, } \\
\text { Uttar } \\
\text { Pradesh. }\end{array}$ \\
\hline Stomach & Tamil Nadu, Goa. & $\begin{array}{l}\text { Andhra Pradesh, } \\
\text { Uttarakhand }\end{array}$ & $\begin{array}{l}\text { Jammu and } \\
\text { Kashmir, } \\
\text { Arunachal } \\
\text { Pradesh, } \\
\text { Sikkim, } \\
\text { Manipur, } \\
\text { Nagaland } \\
\end{array}$ \\
\hline Oesophagus & Karnataka, Assam & $\begin{array}{l}\text { Jammu and } \\
\text { Kashmir }\end{array}$ & None \\
\hline Oral cavity & $\begin{array}{l}\text { Uttar Pradesh, } \\
\text { Gujarat, Pondicherry, } \\
\text { Orissa }\end{array}$ & None & Assam \\
\hline Tongue & $\begin{array}{l}\text { Goa, } \\
\text { MadhyaPradesh }\end{array}$ & None & None \\
\hline $\begin{array}{l}\text { Oro- } \\
\text { pharynx }\end{array}$ & Haryana, Meghalaya & None & None \\
\hline $\begin{array}{l}\text { Naso- } \\
\text { pharynx }\end{array}$ & None & Manipur, Assam & None \\
\hline Neck & None & Tripura & Uttarakhand \\
\hline Larynx & None & Uttarakhand & None \\
\hline
\end{tabular}

Source: Cancer India growth statistics ${ }^{12}$

Table 2 shows the State-wise distribution of tobacco related cancers in India. It shows that the states highly affected with oral cancer in India are Uttar Pradesh, Gujarat, Pondicherry, Orissa. The least affected state in India with oral cancer is Assam.

TABLE 3: CANCERS COMMON AMONG MALE, FEMALE AND CHILDREN IN INDIA

Volume No: 8 , Issue No: 4

\begin{tabular}{|l|l|l|}
\hline \multicolumn{1}{|c|}{ Male } & \multicolumn{1}{|c|}{ Female } & \multicolumn{1}{c|}{ Child } \\
\hline Oral Cavity & Oral Cavity & Leukemia \\
\hline Oesophagus & Breast & $\begin{array}{l}\text { Central nervous system and } \\
\text { Brain related tumours }\end{array}$ \\
\hline Leukemia & Thyroid & Lymphoma \\
\hline Pharynx & Stomach & Wilms tumour \\
\hline Stomach & Leukemia & Neuroblastoma \\
\hline Lymphoma & Oesophagus & Bone Cancer \\
\hline Lung & Ovary & Retinoblastoma \\
\hline Brain and Nervous & Cervix & Rhabdomyosarcoma \\
system & Pharynx & Osteosarcoma \\
\hline Liver & Lymphoma & Ewing Sarcoma \\
\hline Larynx &
\end{tabular}

Source: Cancer India growth statistics ${ }^{12}$

Table 3 shows Cancer common among Men, Women and Children. Oral cancer is more prevalent in case of men as well as women in India.

TABLE 4: TRENDS IN THE PREVALENCE OF TOBACCO CONSUMPTION AMONG ADULTS IN INDIA BEFORE AND AFTER NATIONAL TOBACCO CONTROL PROGRAM

\begin{tabular}{|l|l|l|}
\hline YEAR & $\begin{array}{l}\text { SMOKELESS } \\
\text { TOBACCO }\end{array}$ & $\begin{array}{l}\text { SMOKED } \\
\text { TOBACCO }\end{array}$ \\
\hline \multicolumn{3}{|l|}{ Before National Tobacco Control Program } \\
\hline 1987 & $15.0 \%$ & $19.8 \%$ \\
\hline 1993 & $13.2 \%$ & $17.2 \%$ \\
\hline 1995 & $14.1 \%$ & $17.6 \%$ \\
\hline 1998 & $17.2 \%$ & $13.7 \%$ \\
\hline 2005 & $23.4 \%$ & $18.3 \%$ \\
\hline After National Tobacco Control Program \\
\hline 2009 & $24.2 \%$ & $11.9 \%$ \\
\hline 2015 & $17.6 \%$ & $12.5 \%$ \\
\hline 2016 & $19.3 \%$ & $8.6 \%$ \\
\hline
\end{tabular}

Source: Trends in tobacco consumption in India 19872016: impact of the World Health Organization Framework Convention on Tobacco Control. International journal of public health. 2019;64(6):841-51 ${ }^{13}$.

Table 4 shows the trends in the prevalence of tobacco consumption among adults in India before and after National Tobacco Control Program. It shows that the usage of smokeless tobacco has decreased to $17.6 \%$ in 2015 after the implementation of National Tobacco Control Program 
from $23.4 \%$ in 2005 . Same way the prevalence in the usage of smoked tobacco has reduced considerably from $18.3 \%$ in 2005 to $11.9 \%$ in 2009 after the implementation of National Tobacco Control Program.

TABLE 5: TOBACCO RELATED CANCERS IN MAJOR CITIES OF INDIA BEFORE AND AFTER NATIONAL TOBACCO CONTROL PROGRAM

\begin{tabular}{|l|l|l|l|l|}
\hline YEAR & MUMBAI & CHENNAI & DELHI & BANGALORE \\
\hline \multicolumn{4}{|l|}{ Total number of persons } \\
\hline $\begin{array}{l}2000- \\
2004\end{array}$ & 7642 & 1288 & 7467 & 3219 \\
\hline $\begin{array}{l}2004- \\
2005\end{array}$ & 5411 & 2622 & 5958 & 2401 \\
\hline $\begin{array}{l}2006- \\
2008\end{array}$ & 8547 & 3254 & 6793 & 2955 \\
\hline $\begin{array}{l}2009- \\
2011\end{array}$ & 5917 & 1046 & 7621 & 3213 \\
\hline $\begin{array}{l}2012- \\
2014\end{array}$ & 3625 & 2217 & 5326 & 1905 \\
\hline
\end{tabular}

Source: Ncdirindia.org ${ }^{14}$

Table 5 shows tobacco related cancers in India before and after National Tobacco Control Program. It shows that in Mumbai, the number of cancer patients due to tobacco usage has decreased from 7642 to 3625 . In contrast, the total number of cases in Chennai has increased from 20002014.

\section{DISCUSSION:}

Tobacco use slaughters almost 6,000,000 individuals every year worldwide. According to World Health Organization (WHO), all inclusive, there were about 100 million unanticipated deaths due to tobacco in the 12th century. In case if the current pattern of tobacco usage proceeds, this number is required to ascend in the 21 st century to 1 billion ${ }^{15}$ in India; tobacco is a major public health burden. The total cancer cases due to tobacco usage are nearly $45 \%$ of cancer in males and $20 \%$ of cancers in females ${ }^{16}$. This study aimed to compare the incidence of tobacco related cancers before and after implementation of National Tobacco Control Program.

In the present study, table 1 shows the Incidence of Cancer before and after NTCP in Males and Females. It shows that there is an increase in terms of cancer patients after 2008 that is after the implementation of National Tobacco Control Program. The total number of cancer patients has increased from 83000 in 2005 to 123000 in 2019.Although the various tobacco control programs implemented in India should have reduced the usage of tobacco, there is a rise in cancer. This could be due to the flaws in planning and implementation of National Tobacco Control Program or might be the various other confounding factors too.

Tobacco is dangerous in any structure or camouflage. Logical proofs have unequivocally settled that usage of tobacco causes demise, infections and various disabilities ${ }^{17}$. According to the "International Agency for Research on Cancer" (IARC) monograph, there is enough evidence in human beings that smoking tobacco causes disease of the oral cavity, lung, oro, naso and hypo-pharynx, paranasal sinuses and nasal cavity, larynx, throat, pancreas, stomach, kidney, liver, urinary bladder, ureter, cervix and bone marrow. Colorectal malignancy supposedly is related with smoking cigarettes, although there are no sufficient evidences, for it to be the cause ${ }^{18}$. Such tobacco related cancers and their state-wise distribution in India are discussed in Table 2. The states highly affected with oral cancer in India are Uttar Pradesh, Gujarat, Orissa which might be due to habit of smoking and tobacco usage being high in these states. The study done by Goud ML et al ${ }^{19}$ showed a significant association of tobacco chewing and oral disease with a direct connection with the amount and term of use proves these findings. Pednekar et $\mathrm{al}^{20}$. In their study in Mumbai unveiled that the frequency of oral malignant growths was $42 \%$ higher in bidi smokers than that of cigarette smokers. Same way these might be the reason for oral cancers being more prevalent among men and women in India according to table 3.

Results in table 4 show that the usage of smokeless tobacco has decreased to $17.6 \%$ in 2015 after the implementation of NTCP from $23.4 \%$ in 2005. Same way the prevalence in the usage of smoked tobacco has reduced considerably from $18.3 \%$ in 2005 to $11.9 \%$ in 2009 after the implementation of NTCP. This might be attributed to the 2013 ban of sale, manufacture and distribution of Gutka, a smokeless, chewed form of tobacco containing areca nut in various states of India such as Andra Pradesh, Tamilnadu, Maharashtra, Assam, Madya Pradesh and Gujarat. The implementation of pictorial warnings in cigarette packets under the Cigarette and Other Tobacco Products Act in 2003 and advertisements on the ill effects of tobacco usages could also be a reason ${ }^{8}$.

In the present study, table 5 shows tobacco related cancers in India before and after National Tobacco Control Program. It shows that in Mumbai, the number of cancer patients due to tobacco usage has decreased from 7642 to 3625. Whereas in Chennai, the total number has increased from 2000-2014. These findings can be due to the high illegal availability of tobacco products in a major city like Chennai. Vidhubala $\mathrm{E}$ et $\mathrm{al}^{21}$ in their study have reported that the ban on smokeless tobacco has been systematically 
violated in Chennai city due to which there might be illegal availability of such tobacco products in large amounts, which can be regarded as a reason for such a finding in the present study.

The "Ministry of Commerce and Industry", Government of India under the "Tobacco Board Act" in 1975, initiated the Tobacco Board, replacing the "Tobacco Export Promotion Council". The Tobacco Board Act, 1975 aims at the development of Tobacco Industry in the country. It regulates the production of Virginia Tobacco with regard to the demand in India ${ }^{22}$. On the other hand, the "Ministry of Health and Family Welfare" have implemented National Tobacco Control Programme and the National Tobacco Control cell to control tobacco products in India. Inspite of rise in the usage of tobacco and tobacco related cancers in India; the government promoting the production of tobacco and tobacco industries is a menace. The fact that on one hand India promotes the production of tobacco promotion board for the high revenue in this field and on the other hand trying to control tobacco by implementing National Tobacco Control cell can be an act of duplicity. The revenue from tobacco products in India being 19255 crores is the major reason for the promotion of tobacco products in India. Direct medical expense of treating disease related to tobacco in India is about $\$ 907$ million in case of smoked and \$285 million in the case of smokeless tobacco. Promoting tobacco for its midget revenue and spending double the cost to treat its complication is vapid. It can be looked through as a total waste of time, money and energy. Strict action to ban tobacco products must be taken to rule out the deaths due to tobacco.

Public health awareness programmes, raising any mass development against usage of tobacco and cancer due to its use, sharpening and instructing all human services experts for tobacco control and educational programs on cancers, nursing educational plan, different CMEs, meetings, scientific meetings, workshops are being done in India but are not viable at all in a country like ours. There is a major difference between awareness, control and ban which is the understanding needed. Awareness could not help whereas control can slightly bring down the tobacco usage, but only bans on tobacco can halt this public health disaster. Strict bans on tobacco and its products can only be a panacea. The ban on Gutka, a smokeless, chewed form of tobacco containing areca nut in various states of India such as Andra Pradesh, Tamilnadu, Maharashtra, Assam and Gujarat must be implemented in all the other states also to bring down the cancers due to tobacco usage.

Tobacco usage is the leading cause of preventable deaths all over the world ${ }^{23}$. India has probably the most noteworthy pace of oral malignant growth on the planet, with over half of it from smokeless tobacco use ${ }^{24}$.

Even after the implementation of strict tobacco control acts if the tobacco usage and cancer related to it have not reduced a considerable amount in India, then there might be other confounding factors which might be the cause for such cancer. Hence all such factors have been discussed in this study.

Environmental pollution in industrialized Western countries, concerns that air pollution is the main cause of lung cancer in the current day scenario. This is based upon the fact that some carcinogens are still being released into the external environment from sources such as industries, motor vehicles and power plants ${ }^{25}$. This could eventually be a confounding factor causing cancer in humans other than tobacco products.

Irrational use of pesticides in the food products has made it poisonous which can be the major cause for cancers in India. Arsenic, Benzene, Ethyl oxide, Formaldehyde and Sulfax used in turmeric, ethephon used to ripen mangos and chillis, are turning to be major cancer causing carcinogens. Organophosphate pesticides like fonofos, phorate, and parathion which are very harmful for the human body and are carcinogenic are being used in wheat crops ${ }^{26}$. These can be the potential reason for rise of cancer in India even after the implementation of strict rules and programs for the control of tobacco in India.

\section{RECOMMENDATIONS:}

Exact factors:

1. Public health awareness, different CMEs, meetings, scientific meetings, workshops are being done in India but are not viable at all in a country like ours. Strict bans on tobacco and its products can only be a panacea.

2. A strong ban on tobacco products, smoke or smokeless must be immediately implemented to overcome this public health burden of increasing tobacco related cancers in India.

3. Agricultural promotion of tobacco must be banned to stop its production such that the usage of addictive nicotine tobacco reduces.

4. Prohibition of smoking in public places which includes workplaces, shopping malls, airports, bus and train stations, hotels, cinema halls, shops and restaurants is a rule under COTPA, in-spite of which people smoke in public places which is the major problem concerned with second hand smoke which is affecting non tobacco users also. Strict 
action must be taken against those who prohibit the law to reduce the cancers in India.

5. Strict implementation of COTPA rules must be done to reduce the usage of tobacco in India. Smoking in roads causing cancer to others due to second hand smoke must be punished severely. Road side shops selling tobacco products must be banned and punished.

\section{CONFOUNDING FACTORS:}

1. Pesticides that are banned in United States, Brazil and chine are still being used in India. All that should be banned. Organic farming must be encouraged and practiced by all the people to reduce the incidences of cancer due to pesticides. Food control officers must be appointed to control the adulterations in food which causes cancer.

2. Pollution control board must take action to reduce the pollution that is a major confounding factor causing cancer.

\section{CONCLUSION:}

By the analysis of incidence of tobacco related cancers and tobacco consumption in India, it is evident that the usage of tobacco products both smoke and smokeless tobacco consumption have decreased after the implementation of NTCP and in the same manner, the incidence of tobacco related cancers have declined in Mumbai, Bangalore and Delhi but has raised in case of Chennai. If the above recommendations or not followed and put into action, India might soon transform to be a graveyard of tobacco users.

\section{FINANCIAL SUPPORT AND SPONSORSHIP}

Nil

\section{CONFLICTS OF INTEREST}

There are no conflicts of interest.

\section{REFERNCES:}

1. Elango JK, Gangadharan P, Sumithra S, Kuriakose MA. Trends of head and neck cancers in urban and rural India. Asian Pacific journal of cancer prevention. 2006;7(1):108-11.

2. Sankaranarayanan R, Ramadas K, Thomas G, Muwonge R, Thara S, Mathew B, Rajan B, Trivandrum Oral Cancer Screening Study Group. Effect of screening on oral cancer mortality in Kerala, India: a cluster-randomised controlled trial. The Lancet. 2005;365(9475):1927-33.
3. Manoharan N, Tyagi BB, Raina V. Cancer incidences in rural Delhi-2004-05. Asian Pac J Cancer Prev. 2010;11(1):73-7.

4. Khandekar SP, Bagdey PS, Tiwari RR. Oral cancer and some epidemiological factors: A hospital based study. Indian J Community Med. 2006;31(3):157-9.

5. Fritzetal.,International Classification of Diseases For Oncology, World Health Organization, Geneva, Switzerland, 3rd edition, 2000.

6. Conway DI, Petticrew M, Marlborough H, Berthiller J, Hashibe M, Macpherson LM. Socioeconomic inequalities and oral cancer risk: a systematic review and meta-analysis of case-control studies. International journal of cancer. 2008;122(12):2811-9.

7. Kumar S, Heller RF, Pandey U, Tewari V, Bala N, Oanh KT. Delay in presentation of oral cancer: a multifactor analytical study. National Medical Journal of India. 2001;14(1):13-7.

8. Rath R, Krishnan A, Nongkynrih B, Misra P. Assessment of implementation status of Cigarettes and Other Tobacco Products Act (COTPA) and its awareness among residents in a block of Haryana. Indian J Public Health 2018;62:100-3

9. Kaur J. National Tobacco Control Programme - a critical review and steps forward. Health for the millions 2012;38:8-16.

10. Ministry of Health and Family Welfare. Operational guidelines: national tobacco control programme. http://www. nhmmp. gov. in/ WebContent/ Tobako- 29102015/ OperationGuideline. pdf (accessed 4Feb 2020).

11. Ministry of Health and Family Welfare. Union Budget Demand no. 2018;42. https:// www. indiabudget. gov. in/ ub2018- 19/ eb/ sbe42. pdf.

12. Cancer India growth statistics details figures [Internet]. Indiastat.com. 2020 [cited 3 February 2020]. Available from: https://www.indiastat.com/healthdata/16/diseases/77/cancer/17811/ stats. Aspx

13. Abdulkader RS, Sinha DN, Jeyashree K, Rath R, Gupta PC, Kannan S, Agarwal N, Venugopal D. Trends in tobacco consumption in India 19872016: impact of the World Health Organization Framework Convention on Tobacco Control. International journal of public health. 2019;64(6):841-51.

14. NCRP Anual Reports.[Internet]. Ncdirindia.org. 2020 [cited 7 February 2020]. Available from: http://www.ncdirindia.org/NCRP/Annual_ 
15. The MPOWER packge, warning about the dangers of tobacco. Geneva: WHO; 2011. WHO Report on The Global Tobacco Epidemic, 2011.

16. Malhotra RK, Manoharan N, Nair O, Deo S V, Rath GK. Trends and future burden of tobaccorelated cancers incidence in Delhi urban areas: 1988-2012. Indian J Public Health 2019;63:33-8

17. A global epidemic of addiction and disease. Tobacco: deadly in any form or disguise. World Health Organization. WHO Tobacco Free Initiative. World No Tobacco Day 2006. Available from: http://www. who.int/tobacco/ communications/events/wntd/2006/Report_v8_4M ay06.pdf [Last accessed on 2020Feb 6].

18. Tobacco Smoke and Involuntary Smoking. IARC Monographs on the evaluation of Carcinogenic Risks to Humans. IARC; 2002; 83.

19. Goud ML, Mohapatra SC, Mohapatra P, Gaur SD, Pant GC, Knanna MN. epidemiological Correlates between Consumption of Indian Chewing Tobacco and Oral Cancer. eur J epidemiol 1990;6,2:219-22.

20. Pednekar MS, Gupta PC, Yeole BB, Hébert JR. Association of tobacco habits, including bidi smoking, with overall and sitespecific cancer incidence: Results from the Mumbai cohort study. Cancer Causes Control 2011;22:859-68.

21. Vidhubala E, Pisinger C, Basumallik B, Prabhakar DS. The ban on smokeless tobacco products is systematically violated in Chennai, India. Indian journal of cancer. 2016 Apr 1;53(2):325-30.

22. Tobacco Board, Guntur [Internet]. Tobaccoboard.com. 2020 [cited 12 February 2020]. Available from: https://tobaccoboard.com/ bactivities.php

23. Prabu D, Nirmala S, Aurlene N. Tobacco Menace and Challenges in Quitting Tobacco in an Indigenous Population of Tamil Nadu: A Crosssectional Survey. Journal of Clinical and Diagnostic Research.2019:13(4):ZC15-ZC20.

24. Boffetta P, Hecht S, Gray N, Gupta P, Straif K. Smokeless tobacco and cancer. Lancet Oncol 2008;9:667-75.

25. Cohen AJ. Outdoor air pollution and lung cancer. Environmental health perspectives. 2000;108(suppl 4):743-50.

26. Pesticides- Diabetes and the Environment [Internet]. Diabetesandenvironment.org. 2020 [cited 12 February 2020]. Available from: http://www.diabetesandenvironment.org/home/con tam/pesticides. 